\title{
Atonement through blood in Leviticus
}

\author{
P M Venter \\ (Universiteit van Pretoria)
}

\section{ABSTRACT}

\section{Atonement through blood in Leviticus}

In the book of Leviticus the notion of reconciliation is used in a cultic context. Sacrifice and blood are the main means in the cult for reconciling man with God. This study investigates reconciliation in Leviticus in terms of concepts like sacrifice, purity, atonement, apropiation, expiation and substitution. This is done against the background of the book's contents, the ideas of its probable priestly authors and the ideology in these circles of the cult in Israel.

\section{INTRODUCTION}

After two parties have been estranged, their relationship can be restored. Quarrels can be settled and they are said to be reconciled with each other. In religious circles profanation can occur. To restore the relationship with God purification can take place by conducting one or another ceremony. This restitution, or reconciliation, usually needs a third party as mediator.

In the book of Leviticus the notion of reconciliation functions in a cultic context. In this idea-world, reconciliation is usually made possible by the use of a non-human object as instrument to restore the relationship between man and God. Other means are possible, but generally sacrifice and blood are used to bring about this reconciliation, or rather, propitiation. Reconciliation should therefore rather be indicated by terms like "propitiation", or "expiation", in this context.

As the notion of reconciliation is used in a unique way in the book of Leviticus, this study aims at elucidating Leviticus' understanding of this process of reconciling man with God. As sacrifice and blood are the main means of reconciliation here, we have to focus on these two terms. These are studied firstly against the background of the book's contents, secondly in relation to the book's probable author(s) and his/their life setting, and finally, according to the book's 
specific perception of the notion of reconciliation in terms of atonement, sacrifice and blood.

\section{THE BOOK OF LEVITICUS IN ITS PRESENT FORM}

The book of Leviticus forms a thematically independent unit within the larger context of the Pentateuch. Exodus describes the construction of the tabernacle and its officials. Leviticus focuses on the living cult. Although Leviticus is sometimes called “The Priest's Manual", it is interesting that all the laws pertaining to the Levites are rather found in the book of Numbers. In Leviticus the role of the priests is mainly to instruct Israel how to avoid defilement and how to regularly cleanse the sanctuary. The cult and its rituals therefore take central stage in Leviticus.

The book concentrates on the particular way in which the holy God can be worshipped by the people whom he elected to belong to him. The book is, however, not merely a collection of rituals. In the book the "ethical element fuses with and even informs the ritual so that one may seek a moral basis behind each ritual act" (Milgrom 1984:541). Vice versa the ritual also has effect on the ethics of the community and their interrelationship with each other.

The sacral-ethical collection of ritual directives in the book are presented in the following units:

- The sacrificial system (chapters 1-7);

- The service of ordination at the sanctuary (8-10);

- The laws of impurity (11-16);

- The Holiness Code regulating conduct (17-26);

- Gifts for the sanctuary (27).

\section{THE LITERARY HISTORY OF THE BOOK}

Comparison of the contents of Leviticus with the contents of the books of Exodus and Numbers, indicates a long literary process of growth. Leviticus 8 seems to continue the discussion in Exodus 29 on the ceremony how to anoint priests at the altar. Information on the religious festivals, like the Passover Festival in Exodus 11:9-12:20,28,40-51, and in the Holiness Code ( $\mathrm{Lv}$ 17-26), indicates that older traditions were used in those books. Law codes referring to the ritual found in Leviticus 1-7, 11-16, 27 and Numbers 5:11-31, 15:37-41 probably 
come from a younger or later stage of growth. Secondary restatements, of which most occur in Numbers, indicate a still younger stage. Numbers 5:1-10 reflects Leviticus 5 and 12-15. Numbers 9:1-14 mirrors the ancient material of Exodus 11-12. Numbers 15:1-36 seems to be a further development of Leviticus 1-7. Mythic narratives were probably added to Leviticus in a final phase.

Scholarly theories on the growth of the materials are traditionally linked to the activities of a group of priestly writers in Israel. In the exilic and post-exilic time the probably collected traditions on the cult, to legitimize the events at the sanctuary in Jerusalem. Their work is often indicated as "the Priestly source", or simply "P".

\section{ZADOKITE JUDAISM}

One theory on these priestly writers come from Boccaccini (2002). According to his theory a priestly society of Zadokites was formed after the exile. Members of the house of Zadok kept the hereditary high priesthood in the early second temple period. This group was predominant in Israel right up to the Maccabean revolt in the second century BCE. They represented a flow of tradition which Boccaccini calls “Zadokite Judaism”. Their major literary accomplishments in the second temple period, were the autonomous traditions associated with Nehemiah and Ezra, the Priestly writing (P) and the books of Chronicles.

In this society the boundaries of the cosmic and social structures were defined. Order was a value that encompasses the entire range of cosmic and human relationships. According to the boundaries set by this order one is embedded in family, society, culture and the universe. God organised the cosmos by defining boundaries of time, space and society. The preservation of this cosmic system is dictated by a coherent mechanism of "graded holiness". This consisted of an orderly and related hierarchy of living beings, space and time. Within this graded scale each element is assigned a place and a role.

The Zadokite priests were at the top of the social hierarchy of living beings. On the scale of human beings they were followed by the Aaronite priests, the Levites, male Jews, female Jews, gentiles, clean and unclean animals. On this cultural map each class of living beings was categorised according to the Israelite classification system and 
subjected to different purity laws. This system defined their mutual relations and their cultic responsibilities toward God. In spatial terms decreasing sanctity applied in concentric circles as one moved away from the sanctuary. In chronological regard sacred and ordinary days were distinguished and everything was ordered around the Sabbath and in terms of a seven-day cycle.

There was a strict connection between the cosmic and the moral order. If the boundaries were crossed without proper rituals or without being in a proper state, the stability of the entire system was jeopardised. There was a fragile balance that had to be kept.

God's care for the created world urged people's active cooperation. It was in humans' interest to keep the balance and enjoy the benefits of stability and order. The Zadokite civil and cultic laws were focused on sanctioning boundaries, maintaining and correcting them so that the world remains a stable and enduring sphere of ordered relations. Law in human society was the extension of the need for order in the realm of social behaviour. When Israel complied with the purity and moral laws of the covenant, stability and survival for the Jewish society as well as the entire world was brought about. The covenant was therefore the foundation of an orderly and balanced relationship between God and his people by its providing of precise boundaries.

\section{THE CONTENTS OF RECONCILIATION IN LEVITICUS}

The contents of Leviticus derive in its entirety from Priestly sources. It functions against the background pictured above. It also moves along the same line of thinking of the other Zadokite materials. Its prescriptions and rules, however, reflect distinct shades of that priestly Zadokite theology. The book generally deals with issues like sacrifices and offerings; cleanness and uncleanness; and holy living. For the purpose of this investigation into reconciliation in Leviticus, we now turn to the book's specific notion of reconciliation in terms of transgression and atonement, its conceptualisation of sacrifices and the meaning of the ritual use of blood.

The basic order in the world depends on the relationship between Yahweh and Israel. This relationship forms the basis of a social network of relationship. This network has an ethos of its own. It follows specific rules. This ethos can be described as "holiness". This 
idea plays the central role in Leviticus. Yahweh is intrinsically holy. Any person or thing standing in relationship to him is also called holy.

Within the cosmic order holy primarily means to be whole. To keep God's order, to remain in the place allocated to you and to hold everything in equilibrium, is to keep God's order intact. You are then holy, whole, pure, and just. Purity is to "observe the system of space and time lines that human groups develop to have everything in its place and a place for everything” (Pilch 1993:151).

To cross the lines that create distinct places and roles, is to render a person impure and unclean. Purity, for example, is threatened at the margins when these boundaries become porous and permeable. Purity is endangered by body openings at the very margin of the human body. These are indicated in Leviticus 11 dealing with clean and unclean food, 12 on childbirth, 13-14 about repulsive scaly conditions and 15 dealing with male and female body efluvia. Laws found in these sections deal with the way in which purity is threatened and how it might be regained.

To be disobedient to God's laws means to transgress these borders and disturb the order. Sin places a person's relationship with Yahweh in jeopardy. It is also detrimental to the community's welfare and solidarity and the cosmic relations. It destroys God's created order. It endangers the orderly and balanced relationship between the different areas of life and between God and man. Man's sin and impurity disturb this balance and evoke God's wrath and punishment. The sins committed produce a complex pattern of consequences, personal, social, as well as spiritual. It causes an obligation to hang over the head of the sinner. He becomes unholy, unclean, impure, defective, and false. Man then has to "carry" his iniquity. This is the burden that accompanies his sin in the form of either the penalty or the retributive punishment that attends a sinful act. The person himself experiences that burden as guilt.

The sinful act unleashes impurity, which is attracted to the sanctuary. Sin in the priestly doctrine is a type of miasma that is attracted magnetically to the holy places and people set apart for God. It adheres to the sanctuary and amasses there until God will no longer bear with the sanctuary. 
Israel personalised impurity. They transformed the idea of demonic evil into human evil. As Israel demythologised all powers and evil, only one source of evil remains and that is man himself. He alone is responsible for the disruption of God's order. His physical and moral impurity breaks down the balance, pollutes God's sanctuary and drives God from their midst. It is therefore forever incumbent upon Israel himself to rectify the destabilisation brought about by their sin. Holy place, person and time have to be regularly purged of their impurities to avoid God abandoning Israel.

This purging was, so to speak, done on invitation. In Israelite religion Yahweh was known as the God who wants harmony to be restored. In Israel's mind God has placability. He is always willing to forgive. As Schenker (1981:82) said: “JHWH ist versöhnlich!” Because of his readiness to restore his relationship with Israel he provided the actions through which his relationship with Israel could be repaired. He invited Israel to perform them. The unbroken repetition of cultic acts indicated and guaranteed God's preparedness for remission of punishment. Although it is the priest who makes expiation for the people's guilt, it is God himself who actually forgives them. Israel only has to accept these measures and follow God's directions. The person taking consciously part in the atonement rituals assert his guilt and simultaneously confesses God as the one who is willing to restore the relationship.

The actions to restore the relationship with God, could take many forms. In Leviticus these measures include ritual as well as ethical acts. They occurred in nearly every feast and dedication of office bearers at the sanctuary. They took the form of offerings, shedding blood, presenting items like frankincense, silver or fine flour to God. They were performed on days of feasts and on the Day of Atonement. The call upon Israel to be holy because their God the Lord is holy (Lv 19:2), found in the section of the Holiness Code ( $\operatorname{Lv}$ 17:1-26:46), also includes various areas. Laws are presented for different sacrifices, sexual relationships, everyday conduct, marital relationships, attending to the soil, and to different religious festivals. In all of these Israel uncompromisingly turned to God, as the sole dispenser of expiation. All of these measures were based on Yahweh's willingness to forgive and to be reconciled with his people. They presented the possibility 
God created to be reconciled with him. They presented both relieve of punishment as well as guarantee of God's forgiveness.

These acts of repairing the relationship with God are referred to in most of the cases with the Hebrew term dpk $(k f r)$. This term can be translated with different English words. It was a concept which evolved through a series of meanings. Initially the word indicated an action that eliminates dangerous impurity. In a next phase it indicated the presentation of a ransom or substitute. It later developed the meaning of expiation.

\section{SACRIFICE AS MEANS OF RECONCILIATION WITH GOD}

To restore God's order and to avert divine judgment, asks for specific measures. As already indicated these measures include ritual as well as ethical acts in Leviticus. Rituals were performed in the cult with its tabernacle, furniture, artefacts, priests, sacrifices and sacred seasons.

The cult at the temple had the dual function of restoring as well as maintaining the creative order. Some sort of evil and impurity, deliberately or undeliberately, individually or corporately, could not be avoided. The cult therefore, played an essential role in providing rituals of reparation and purification to avert God's wrath and punishment. By means of the ritual the divine order that is disturbed by impurity or sin, is restored once more to its original harmony. By this means the "people are offered a way back to their proper status provided that in their freedom they are eager to fulfil the required conditions for purification” (Boccacini 2002:81).

The elaborate religious rituals found in Leviticus formed an important aspect of compliance. According to McVan (1993:32)

"Compliance is an integral aspect of cultural cohesion in societies in which strict adherence to social codes and patterns of living is demanded. Ritual compliance to God's laws assign cultural and ethnic boundaries, determines purity (e.g. Lv 5:1-13, 13-15), certify status and define communal membership".

The system of ritual maps the cosmos, guides one's passage through it and institutes sanctions against those who did not comply with its vision of reality. The compliant person by his actions and his 
behaviour, demonstrates his/her conviction regarding the system of cultural and religious values which constitutes and orders the society of which $\mathrm{s} /$ he is a member.

One of the main rituals is sacrifice. Sacrifices offered at the tabernacle were essential for Israel to find expiation from her sins and thus to continue to be acceptable to Yahweh. Sacrifice brings about expiation or atonement. The offering of the appropriate sacrifice was the way Israelites addressed the multiple consequences resulting from a sin. It brought restoration of the equilibrium. Restoring and maintaining this equilibrium is in essence holiness ( $\mathrm{Lv} 11: 44-47,20: 22-26)$. To be holy, to become whole again, bears the dual connotation of "sanctification" (by emulating God's nature 11:44a) and "separation" (from the impurities of the pagans 20:23-26).

In the book of Leviticus regulations and instructions for various types of sacrifices are given, along with the materials appropriate for each sacrifice, and the various ritual procedures. These sacrifices consisted of two categories. To the first category belonged sacrifices that can be presented if one so desires. These included the whole offering, the grain offering, and the offering of well-being (chaps. 1-3). The burnt offering ( $\mathrm{Lv} 1$ ) or whole offering primarily symbolized the total dedication of the one who sacrifices. The subject presented tribute or grain/cereal offering ( $\mathrm{Lv} 2$ ) to create goodwill and to bring tribute to the overlord. The peace/communion/ well-being offerings ( $\mathrm{Lv} 3)$ do not serve as expiation. They basically serve the purpose of conducting a meal in which God and his people take part. The sacrifice emphasizes communion, following upon reconciliation with the Lord, and/or the dedication of the offerer to the Lord.

To the second category belonged sacrifices to expiate a sin. The sin/purification offering (4:1-5:13) and its borderline cases (Lv posed in the ritual. The guilt/reparation offering and the reparation offering (5:14-19, 20-26[6:1-7]) were for expiation from an offense for which restitution was possible, or for violation of anything sacred. Either individuals or the congregation brought these two types of sacrifices because of one or another specific sin. They expiated transgressions, such as those against the holy things, those against the divine commandments, and those against God himself. 
On the Day of Atonement ( $\operatorname{Lv} 16: 1-34 ; 23: 27-32$ ) both the temple and the people were purged. A rich variety of rituals were performed with the dual purpose to bring forgiveness for the covenant people of God from all their sins and freedom from the power of sin. Also different sacrifices were used on this day to bring atonement. Aaron not only sacrificed for himself and his house but also offered the sin-offering of a goat for the congregation of Israel and remitted a second goat outside the camp to die. These different sacrifices indicated different aspects of reconciliation/atonement.

Insight into ancient Israel's view of sacrifice can be discerned from key terms in these sacrifice regulations and from the structures in which they are given. However, although elaborate rules and indications are given for the sacrifices, they do not articulate the ideology underlying the sacrificial system. This lack has led to the formulation of multiple theories as to the meaning of sacrifice.

\section{THE PROBABLE RATIONALE OF THESE SACRIFICE}

In comparative religion four purposes are identified for sacrifices:

- They provide food for the god;

- they assimilate the life force of the sacrificial animal;

- they bring unity with the deity;

- they induce the aid of the deity.

When sacrifices are performed as religious-cultic rites in the context of fixed rituals, they are offered to certain deities in connection with petitions or thanksgivings. In Israel the main purpose of sacrifices are especially linked to this last purpose of petition and giving thanks to God.

These sacrifices had a denotative character. In Ricoer's terms they served as metaphors having a "heuristic fiction" of reality. They had "semantically motivated emphasis" (Stegeman 2001:313). Sacrifices were the primary means by which a person or the community as a whole could overcome the wrongs produced by sin. Sacrifice restored the disturbed balance between the different areas of life and between God and man. It could avert God's wrath and his punishment. Playing a central role in the religion of Israel, the ritual sacrifice was understood as a measure instituted by God for his people to atone their sin. In their minds it is God himself who provides the atoning possibility of 
sacrifice. The presentation of a sacrifice is both sign and proof of Yahweh's placability. Man can be reconciled to God because God is reconcilable. Yahweh guarantees that the ritual sacrifice he prescribed, brings about atonement: "I appoint it to make expiation on the altar for yourself" (Lv 17:11).

The meaning of sacrifices can be found in three areas:

- as a gift to God;

- as a means of expiation;

- and as a means of communion.

A sacrifice was primarily a gift to Yahweh in recognition of his sovereign lordship. A citizen who enters the presence of a king, brings along a gift for the king. When a worshiper approaches Yahweh, the King of Israel, he presents a gift. The various sacrifices represented different kinds of gifts. The presentation of a whole offering was an act of homage and devotion. A purification offering or a reparation offering was a present of contrition and supplication. An offering of well-being was a gift of joyful praise or gratitude, and on occasion it was a gift of appreciative obligation.

Usually in cases of reconciliation between two human parties, full compensation has to be made by the person who is in the wrong. In the case of Yahweh and Israel, God's people are the guilty party. God now offers them the opportunity to be reconciled to their God. Within the cultic setting they are to present sacrifices to God as means of expiation. This sacrifice does not, however, nearly compensate for the damage done by the people. A more mellow measure is taken. The sacrifice is therefore rather a gift or present than a full ransom for the damage done. The sacrifices God asks from his people, express his willingness to be reconciled to his people, taking the sacrifice as a gift or present they present to him. Harsh retribution is replaced in this case by an invitation to rather bring a gift for God. The offerer is saved from severe punishment. His faithful act restores his relationship with God. Reconciliation is therefore in this sense not really a substitutionary punishment in which a guiltless third party takes over the punishment on behalf of the guilty party. The guilty party fully keeps the blame, but is relieved from the punishment in that a much lighter "punishment", is 
meted out. Although the punishment is retained, it rather denotes forgiveness.

To understand the sacrifice as a means of expiation is problematic in some sense. In a ritual context the sacrifice always refers to the sanctuary and not to a person. The blood used as an agent in the sin offering "rubs off" or purges the sanctuary. Either by physical impurity (Lv 12-15), inadvertent transgression against God (Lv 4), or inadvertent misdemeanour against God, people caused the sanctuary and its sanctums to become polluted. The sacrificial blood purges this contamination and makes it once more acceptable for God. As the sacrifice purges the sanctuary rather than the person, it is technically not correct to say that the sacrifice brings about "atonement". People are never the object of the purging ritual, only its beneficiary. The ritual is never performed upon man, but for the sake of the person, outside of him. It brings forgiveness and therefore atonement for him. The concept here rather bears the dual connotation of "sanctification" and "separation" from the impurities of the heathen.

Sacrifice can also be understood in terms of "propitiation”. God's rage is cooled of or averted when he receives a sacrifice. It does not merely expiate in the sense of cancelling sin. It rather propitiates, in the sense of averting God's punishment. God's righteous judgement and his wrath could not be simply averted. It has to be paid for by the sacrifice appropriated. The sacrifice has therefore rather metaphorical value than qualitative value.

Another term often used is expiation. "Expiate" means to purge the impurity released by a sin, to remove the sinner's guilt with the granting of forgiveness, and to restore the relationship between the sinner and God. In Leviticus 16:20 and 33 expiation of sin is intended. Expiation here has the meaning of "cancellation" or "dismissal”. God waives the penalty for transgressions. The results of the disobedience is wiped away, wiped clean or purged. The penalty is not ransomed, but rather eliminated.

Some scholars understand the sacrifice as "ransom" or "substitute". The idea would then be that objective guilt exists. This can only be removed through sacrifice or substitution. The sacrifice siphons off the wrath of God from the community. The sin is transferred to the 
sacrifice and the sin is thereby eliminated. Yahweh demanded that violation of his holy will, results in death. When the animal looses his life, God's demand was met (cf Lv 17:11,14). The animal was killed in exchange for sparing the life of the worshipper. The sacrifice here carries a substitutionary meaning. The idea that the sacrificial victim endures God's punishment of the sinner is, however a notion in the New Testament not found in Leviticus. The sacrifice serves metaphorically in its death as the ransom that enables the sinner himself to go free.

Still another term that can be used is "redemption". This intends the release of people, animals, or property from bondage through outside help. They are not in a position to release themselves and only someone strong or rich, can bring it about. By accepting the sacrifice presented to him God redeems the sinner from his guilt or bondage. This is the other side of the coin indicated by the term "forgiveness". Although no such specific term is used in Leviticus, it is the intention in many cases. In cases like Leviticus 4:20, 26, 31 and 35 the animal sacrifice pays for sin and brings forgiveness. On the human level restitution aids the restoration of strained relationships. In the case of relationship between the sinner and God, the sacrifice gives expiation and mends their relationship. God forgives the sinner, and the relationship between them is repaired. The person becomes free from guilt and does not longer have to fear any retribution.

Sacrifice understood as a means of communion between Yahweh and members of the community, intends a meal. Along with an animal one could therefore present a grain offering, salt, oil, and wine (e.g. $7: 12-13)$. The primary sacrifice for a shared meal between Yahweh and a family was an offering of well- being, for the majority of the meat was returned to the offerer. The meal from that sacrifice strengthened the spiritual bond between Yahweh and that family.

\section{SHED BLOOD: LIFE OR DEATH?}

The final question we have to answer is why the sacrifice for reconciliation also included blood. The handling of the blood was central in the ceremony and was the most crucial part of the ritual. The law of Yahweh had endowed blood this importance. The importance of blood can be seen in the rule that the priestly portions of the sacrifice 
were assigned to the one who manipulates the blood ( $\operatorname{Lv} 6: 26)$. The importance of blood is also underscored by different terms indicating it essential role in expiation (Lv 6:26; 7:7; 16:16-18; 17:11).

Blood is important because it is essential for life. As long as it flows in the body that body is alive. Blood let out of the body implies loss of life. Blood outside the human body is not only a disturbance of God's order but is mostly associated with violence and murder. In almost sixty percent of cases where the term "blood" is used in the Old Testament, it refers to death as a result of violence. Shedding human blood is treated as a capital offence. Whoever sheds the blood of a human is to be killed ( $\mathrm{Gn}$ 9:6). Blood is related to the divine: shed blood has uncanny power, as it calls down vengeance that is assured by God.

The shedding of animal blood, however, is allowed in OT law. It even plays an essential role in the sacrificial cult. The code for priests (Lv 1-7) demands various dispositions of blood as an intrinsic part of the sacrificial ritual. It was applied to symbols of the divine presence and power: it was either splashed against the altar, sprinkled in the sanctuary, or smeared to the altar horns. Bringing blood in contact with these holy objects meant to deal with an object that was close to God and thus pleasing to him. It sanctified whatever the blood touched.

Leviticus 17:11 can be seen as the key passage in Leviticus on the blood ritual. It deals with blood as means of atonement. This is the only text in the Old Testament that comes close to giving a reason why blood effects atonement. It presents a younger explanation of the Israelite reconciliation institute by the blood sacrifice. This verse is explicit that "it is the blood, which is the life, that makes expiation".

In the context of Leviticus 17:1-16 the making of any sacrificial offering away from an official altar and the consumption of blood in any form was prohibited. The centralisation of the sacrificial cult at the official sanctuary gives to blood an exquisite meaning. The prohibition to "eat" blood ( $\mathrm{Lv}$ 17:10) is a precautionary measure against any heathen practice where blood is consumed because it is thought to have inherent power and to give life when it is drunk. In Israel is totally forbidden to consume blood for any reason whatsoever. Neither does blood have an apotropaic function placed on the altar to protect God 
from the malignancy of impurity that man brought into the sanctuary. In Israel blood is to be used for a totally different purpose. It receives here a unique function.

The blood is used as an element in atonement because it is the carrier and symbol of life. Elsewhere (Dt 12:23) blood and life are associated with each other, the one indicating the other. God is, however, the source of all life and he is the only one who controls life. Blood and life both stand in close relation to the living God. Blood indicates God's power and his mercy to give life. Because blood is life and life comes from God, blood is near to the divine and therefore holy and efficacious. Handling of blood in a ceremony at the tabernacle appeals to God's sole authority on life. It presents a solemn presentation to God of life.

The sacrifice blood represents a life that has been taken away. It represents death or, to be more exact, a substitutionary death. In ritual context blood reverses the process of death. Usually when blood is shed, life changes into death. In the sacrifice at the sanctuary blood brings about transition from the realm of the death to the realm of life for the person who sacrifices. The one who sacrifices presents blood/life at the altar, being a replacement for his/her own blood/life. The animal's blood represents that of the worshipper. The shedding of the blood of the sacrificial animal releases the individual's life. The blood of the animal is used as substitution for the life of the sinner. Life is surrendered and dedicated to God so that he can transform the life of the one who brings the sacrifice.

The blood rites performed by the priests enable the offerer to approach the Lord without shedding his/her own blood. Because a person cannot approach God without blood, this blood takes the place of his own blood. It serves as a ransom that substitute for the life owed by the offerer. The idea found in Isaiah that one man can take the place of many others and pay the price, is here switched around. The idea of taking another's place is ritually applied here to the animal that dies on the altar and brings life by his shed blood and expiation for the one who sacrificed it. Different from the talio, it is not repayment in equal terms, but an animal that serves as substitute or surrogate for the sinner supplying the ransom for the guilt of a human being. It settles the 
difference between Yahweh and his people and restores the imbalance brought by transgression.

This strange measure rests solely on Yahweh's relationship with Israel and his willingness to be reconciled with them. Israel believed that Yahweh has graciously given his people a visible way to find forgiveness of their sins. When blood functions as means of reconciliation, it does not only signifies life as a gift of God, but also the blood of the sacrifice itself as a gift which God provides as a means through which man can be saved. The sacrificial blood given to man by God in a ritual, is given to God through the mediation of a priest by the one who offers the sacrifice. The generous all-sufficiency of God places man in a position where he can use the opportunity and possibility created by God to offer to God what God has already given to him. This rules out any magical conception of the blood.

This implies that the blood does not operate in terms of any intrinsic ultimate value, but in terms of its function in the ritual act where it symbolises a process in which man is changed. Blood in itself does not effect expiation, only blood from an animal sacrificed before Yahweh according to certain prescribed rituals. Blood has only meaning in terms of God's willingness to forgive sins. It is ordained by God to be used for cleaning ( $\mathrm{Lv} \mathrm{14}$ ) and as instrument for receiving atonement ( $\operatorname{Lv} 17: 11)$.

God himself bestowed expiationary power on blood. The required manipulation of blood teaches that guilt is not automatically removed. It can be removed only by the participation of the guilty person in the way prescribed by Yahweh. Receiving life from God is not inherent in the blood itself or the performance of the ritual, but is granted by God within the framework of the cult as prescribed by him. The offering of a sacrificed animal according to the prescribed ritual, establishes the judicial basis for Yahweh to grant the presenter forgiveness.

The person bringing the sacrifice presents the life of the animal in exchange for his or her own life. On the principle of lex talionis, the ritualistic manipulation of an animal's blood redeemed the life of the one who presented the offering. This, however, has to be understood in its correct context. It functions within a broader scope of reconciliatory acts as reconciliatory instrument. It could not be a ransom in the sense 
of a down payment on the person's life. The sacrifice does not buy back the person's life. The blood has no inherent trade value. In its cultic functionality there is no difference between human or animal blood. Animal blood can stand in for human life although there is a very real disproportion between human life and animal life. The blood rather has symbolical value.

God accommodates animal blood as reconciliatory instrument for redeeming sin. It symbolizes the person's confession that God accommodates the sacrificial blood and that only God can give life. It signifies the offerer's willingness to act on God's terms. The blood's meaning can only be found in its cultic function. God himself ordained the blood sacrifice for his people. It is God who forgives and gives life. He is willing to forgive the sins in and through the ritual actions where he is recognised as giver of life and the one who sustains life. "Blood is not given to God as atonement. Indeed, God is never the direct object of the verb "atone" as though the sacrificial offering must somehow affect him” (McCarthy 1984:115).

In a system which sought to normalise and unify sacrificial practice the expiatory role of sacrifice was emphasized "...the connection between power of expiation and the divine element of life in the blood is practically a general theory of sacrifice” (McCarthy 1984:115).

Blood also functions on other levels of meaning. When blood is applied to a person it removes sin and effects purification. It removes the impurities of the sanctuary and the altar. This can be seen in the goat for Azazel who carried away the sin of the people into the wilderness ( $\mathrm{Lv}$ 16:22). When the high priest was consecrated, blood was rubbed on him that made him and his vestment holy. It has been called a 'ritual detergent' by Milgrom. Blood therefore signifies "purification" and "sanctification". The relationship with God is restored and the people are dedicated to God as his people.

Blood should therefore be understood as marking off the chosen people, signifying their holiness in the basic sense of separation for the divine. Coupled to the universal conviction that the ritual sharing of blood creates quasi-familial relationship, the blood of the sacrifice becomes the symbol of unity with divine life. The blood thus had the 
endowed meaning of expiating, purifying, and bringing man into the divine sphere of life and holiness. It reinstates the order willed by God.

To be reconciled to God therefore means to be restored to life. Its ethical implication is restored relations with the creation and with fellow human beings. It implies balance and equilibrium in the life of the society and the individual. Once being reconciled with God, the faithful ca work towards reconciliation with his fellow human beings.

\section{Consulted literature}

Boccaccini,G 2002. Roots of Rabbinic Judaism. An intellectual history, from Ezekiel to Daniel. Grand Rapids: Eerdmans.

Brichto, H C 1976. On slaughter and sacrifice, blood and atonement. HUCA 47,19-55

Davies, D 1977. An interpretation of sacrifice in Leviticus. ZAW 89(3), 387-399.

Grabbe, L 1997. The book of Leviticus, Currents in Research: BS 5, 91-110.

Grünwaldt, K 1999. Das Heiligkeitsgesetz Leviticus 17-26. Ursprüngliche Gestalt, Tradition und Theologie. Berlin: Walter de Gruyter.

Hartley, J E 1998. Leviticus. Word Biblical Commentary, Volume 4. Dallas, Texas: Word Books.

Hayes, J H Atonement in the book of Leviticus. Interpretation 52(1), 5-15.

Jenson, P P 1992. Graded Holiness: a key to priestly conception of the world. JSOT Suppl 106. Sheffield: Sheffield Academic Press.

Levine, B A 1984: s v Priestly Writers, in: Crim, K (Ed) The Interpreter's Dictionary of the Bible. Supplementary Volume. Nashville: Abingdon, 683687.

McCarthy D J 1984. s v Blood, in: Crim, K (Ed) The Interpreter's Dictionary of the Bible. Supplementary Volume. Nashville: Abingdon, 114-117.

McVan, M 1993. s v Compliance, in: Pilch, J J \& Malina B(eds). Biblical Social Values and their meaning. A handbook. Peabody: Hendrickson, 31-33.

Milgrom, J 1984. s v Leviticus, in: Crim, K (Ed) The Interpreter's Dictionary of the Bible. Supplementary Volume. Nashville: Abingdon, 541-545.

-, 1984. s v Sacrifices and offerings, OT, in: Crim, K (Ed) The Interpreter's Dictionary of the Bible. Supplementary Volume. Nashville: Abingdon, 763771.

-, 1984. s v Atonmenet in the OT, in: Crim, K (Ed) The Interpreter's Dictionary of the Bible. Supplementary Volume. Nashville: Abingdon, 78-82. 
Nicole, E 2004. Atonement in the Pentateuch, in: Hill, C E \& James, F A The glory of the Atonement. Biblical, historical \& practical perspectives. Downers Grove: Inter Varsity Press, 35-50.

Osiek, C 1993. s v Ordering, in: Pilch, J J \& Malina B (eds). Biblical Social Values and their meaning. A handbook. Peabody: Hendrickson, 126-128.

Pilch, J J 1993. s v Purity, in: Pilch, J J \& Malina B (eds). Biblical Social Values and their meaning. A handbook. Peabody: Hendrickson, 151-152.

Stegeman, W 2001. Sacrifice as Metaphor, in: Pilch J J (ed). Social scientific models for interpreting the Bible. Essays by the context group in honour of Bruce J Malina. Leiden: Brill, 310-327. 